\title{
Decision Making in the Process against Children Diversion Dealing with the Law Has not Aged 12 Years
}

\author{
I Pande Ketut Arya Yarsita*, Rodliyah**, RR. Cahyowati** \\ *Student of Magister Law Study Program, Postgraduate Program, Mataram University, Indonesia \\ **Lecture of Law Faculty Mataram University, Indonesia
}

\begin{abstract}
This study aims to examine and analyze the concept of decision making in the diversion process for children facing the law who are not yet 12 years old; and law enforcement decision making in the diversion process for children who are faced with a law that is not yet 12 years old (Study of the Chairperson of the Mataram District Court Number: 22/Pen.Div/2017/PN Mtr). The concept of decision making in the diversion process for children facing the law that is not yet 12 years old is the judge in imposing sanctions for children considering recommendations in the social research report made by community counselors to express and find data and information objectively about the development and background of life children from various sociological, psychological and other aspects while still paying attention to the best interests of the child. Law enforcement of decision making in the diversion process against children who are faced with a law that is not yet 12 years old emphasizes restorative justice which is the goal in the implementation of the diversion of cases of children facing the law. Law enforcement officials both Investigators, Community Guidance and Professional Social Workers conduct deliberations to reach a decision based on restorative justice that prioritizes the best interests of children.
\end{abstract}

\section{Keywords: Verdict, Diversion, Children}

\section{Introduction}

Children are future generations that must be protected by the state. Protection of children must be realized for the sake of maintaining viable survival. In some cases involving children both as perpetrators and victims, they still pay attention to the protection of the survival, growth and protection of these children. This can be seen in Article 28 B Paragraph (2) of the Constitution of the Republic of Indonesia, namely ${ }^{1}$ :

"Every child has the right to survival, growth and development and has the right to protection from violence and discrimination."

Children who are in conflict with the law get an exception in every process of settling a criminal case. This is different when someone who is over 18 years old commits a crime, then he must undergo a judicial process in accordance with the Criminal Procedure Code (KUHAP).

Special treatment of children in conflict with the law is regulated in Law Number 11 of 2012 concerning the Child Criminal Justice System, which is a change to Law Number 3 of 1997 concerning Juvenile Justice. The basis of the special treatment of children in conflict with the law is restorative justice, which is contained in Article 1 Number (6) of Law Number 11 of 2012, namely ${ }^{2}$ :

"Restorative Justice is the settlement of criminal cases by involving perpetrators, victims, families of perpetrators/victims, and other parties involved to jointly seek a just solution by emphasizing recovery back to its original state, and not retaliation."

\footnotetext{
${ }^{1}$ Article 28 B Paragraph (2) of the Constitution of the Republic of Indonesia.

${ }^{2}$ Article 1 Number (6) of Law Number 11 of 2012
} 
Based on the restorative justice, it can be seen that all parties related to both the perpetrators, victims, witnesses, families of the perpetrators/victims, jointly seek settlement of cases outside the Court. Settlement of cases outside the court against child offenders is called diversion, which is contained in Article 1 Number (7) of Law Number 11 of 2012, namely ${ }^{3}$ :

"Diversion is the transfer of settlement of Child cases from criminal justice processes to processes outside of criminal justice."

The diversion process is carried out on children who are 12 years old but not yet 18 years old. The diversion process must be carried out at every level of the juvenile justice process, namely the level of the police, prosecutor's office and examination of child cases at the Court. The diversion process can only be carried out on criminal acts that have been determined in Article 7 Paragraph (2) of Law Number 11 of 2012, namely ${ }^{4}$ :

"Diversion as referred to in paragraph (1) is carried out in the event that a criminal offense committed

is punishable by imprisonment under 7 (seven) years; and not a repetition of a crime".

However, for children in conflict with the law under the age of 12 years cannot be subject to imprisonment sanctions, this can be seen in article 67 of the Republic of Indonesia Government Regulation Number 65 of 2015 concerning Guidelines for Implementing Diversion and Handling of Children Not Aged 12 (Twelve) Year, namely in the event that a child who is not yet 12 (twelve) years of age commits or is suspected of committing a criminal act, the Investigator, Community Advisor and Professional Social Worker make a decision to submit it to the parent/guardian; or include in education, coaching and mentoring programs in government agencies or Social Welfare Institutions in agencies that handle the field of social welfare, both at the central and regional levels, for a maximum of 6 (six) months.

Based on the provisions of several Articles in Law No. 11 In 2012, it can be seen that the focus of the interest is the protection of children in conflict with the law. This is very contrary to the provisions contained in Law No. 35 of 2014 concerning Amendments to law number 23 of 2002 concerning Child Protection. Where in Law Number 35 Year 2014, among others, it provides responsibility and obligations to the state, government, regional government, community, family and parents or guardians in the matter of organizing child protection, as well as increasing the minimum criminal provisions for perpetrators of sexual crimes against children, and the introduction of a new legal system, namely the right to restitution. Regarding this restitution, it is regulated in Article 71D Paragraph (1), namely Every child who becomes a victim as referred to in Article 59 paragraph (2) letter b, letter d, letter f, letter h, letter i, and letter $\mathrm{j}$ has the right to submit to the court the right to restitution which is the responsibility of the perpetrator of the crime.

Based on the Article above, the child of the victim must obtain restitution from the perpetrator of the crime. But in the case of a child in conflict with the law not yet 12 years old, criminal responsibility cannot be requested based on Law Number 11 of 2012. The child of the victim cannot ask for justice related to the crime he suffered. For this reason, there is a norm conflict between Law Number 11 of 2012 which focuses on the protection of children in conflict with the law by Law No. 35 of 2014, which focuses on the protection of victims' children. The conflict is not in accordance with restorative justice which is the main goal in the diversion process if the child in conflict with the law and the child of the victim are both not yet 12 years old. The next problem arises when the settlement of cases of children who are not yet 12 years old as contained in Government Regulation Number 65 of 2015 requires to carry out fair decision making and protect children's rights in accordance with restorative justice.

\section{Research methods}

The type of research used is normative research, namely research that examines and analyzes laws and regulations, legal principles and legal norms that are applied as norms or norms which are the standard of reasonable human behavior. The approach method used is the statute approach, conceptual approach, case approach.In this study, researchers used primary legal materials, namely binding legal material consisting of: 1945 Constitution, Criminal Code and Law Number 11 of 2012 concerning Child Criminal Justice System, Government Regulation of the Republic of Indonesia Number 65 of 2015 concerning Guidelines for the Implementation of Diversion and Handling of Children Not Aged 12 (Twelve) Years. Secondary legal material, namely legal material that provides an explanation of primary legal material consisting of various

\footnotetext{
${ }^{3}$ Article 1 Number (7) of Law Number 11 of 2012

${ }^{4}$ Article 7 Paragraph (2) of Law Number 11 of 2012
} 
literatures and the views of legal experts relating to the problem under study, as well as several case examples to support primary data and tertiary legal materials, namely the Indonesian encyclopedia. Collection of legal materials is carried out by studying documents, literature, and inventory so that primary, secondary and tertiary legal materials can be obtained. Primary, secondary, tertiary legal materials are collected then processed and analyzed qualitatively. Then qualitative analysis is done in a deductive way, namely drawing conclusions from the general to the specific to get clarity on the truth so that it gets a clear picture of the problem being examined.

\section{Results and Discussion}

a) Principles in the Child Criminal Justice System

The juvenile justice system, based on the principles referred to in Article 2 of the Law on the Juvenile Justice System, states that every juvenile justice is carried out based on the principles of protection, justice, non-discrimination, the best interests of the child, respect for children's opinions, Survival in child development, Guidance and guidance of children, Proportion, Deprivation of independence and punishment as ultimum remedium, Retaliation Avoidance.

The most fundamental substance in the Law on the Juvenile Justice System is the explicit regulation of restorative and diversionary justice intended to avoid and distance children from the judicial process so that they can avoid stigmatization of children who are faced with the law and are expected to be able to return to the social environment naturally. Therefore, in relation to the Child as a criminal offender, normatively based on the Criminal Justice System Act the Child is not free from restorative justice and diversion which the author presents as follows:

\section{1) Restorative Justice}

Restorative justice as a concept of punishment aims to find a way to uphold a more just and balanced system of punishment, for example between the interests of perpetrators and victims. However, restorative justice does not only form the purpose of punishment, but what is equally important is the mechanism to achieve the goal. In order to achieve the purpose of punishment as mandated by the Child Criminal Justice System Act, based on Article 5 paragraph (1) the Child Criminal Justice System Law stipulates that the juvenile justice system must prioritize a restorative justice approach. The use of the phrase, "child criminal justice system" in Article 5 paragraph (1) of the Child Criminal Justice System Law, means that the mechanism for achieving goals in the juvenile justice system that prioritizes restorative justice is not only directed at judges, but also directed to investigators, public prosecutors and correctional institutions as a system. The handling of child cases directed at one of the law enforcement tools, of course, can no longer be called the handling of child cases that prioritize the juvenile justice system.

The importance of the role of restorative justice in handling child cases, Article 1 point 6 of the Child Criminal Justice System Law, explains that restorative justice is the settlement of criminal cases by involving perpetrators, victims, families of perpetrators or victims, and other parties involved to jointly seeking a just solution by emphasizing recovery back to its original state and not retaliation. Law The juvenile justice system does not explain further provisions on what is meant by "Restorative justice", except in the general explanation of the Juvenile Justice System Law that restorative justice is a diversion process. This means that all parties involved in a particular crime together solve the problem and create an obligation to make things better by involving victims, children and the community in finding solutions to improve, reconcile, and reassure those who are not based on retaliation.

According to Bagir Manan conceptually restorative juctice contains ideas and principles, including the following: 
a. Build joint participation between actors, victims, and community groups to resolve an event or criminal act. Placing the perpetrators, victims and the community as stakeholders who work together and immediately try to find a solution that is seen as fair to all parties.

b. Encourage perpetrators to be responsible for victims or events or criminal acts that have caused injury or loss to victims. Furthermore, it establishes the responsibility not to repeat the criminal acts he has committed.

c. Placing an event or crime is not primarily a form of violation of law, but as a violation by someone (a group of people) against someone (a group of people). Thus, the offender should be directed at accountability to the victim, not prioritizing legal responsibility.

d. Encourage resolving an event or crime in ways that are more informal and personal than completion in formal and inpersonal ways. ${ }^{5}$

Based on the description referred to by Bagir Manan, it can be understood that there is a model of restorative justice in resolving criminal cases, not all criminal incidents must be resolved through rigid justice channels without seeing the losses suffered by the victims. In contrast to the retributive justice model which only emphasizes retaliation against the perpetrator without seeing a large loss suffered by the victim, restorative justice provides an opportunity for the perpetrator to make amends facing the victim directly on the basis of good intentions to negotiate and understand the losses suffered by the victim to produce an agreement in order to restore conditions.

The process of restorative justice is basically carried out through discretion (wisdom) and diversion, namely the transfer of criminal justice processes outside the formal process to be resolved deliberately, with the aim of obtaining balance or restoring the situation. Settlement through deliberation is actually not new to Indonesia, even customary law in Indonesia does not distinguish between criminal and civil cases, all cases can be resolved by deliberation with the aim of obtaining balance or restoring the situation $^{6}$.

He stressed restorative justice in the Child Criminal Justice System Act, in relation to this discussion, namely that the child is the perpetrator of criminal acts of sexual intercourse with children, in the event that the settlement is carried out with a restorative justice approach. Approach to restorative justice in the Law The juvenile justice system, where the position of victims and perpetrators who are still in the category of children, must be treated without discrimination from actions that can hinder children's growth and development. The use of the concept of "restorative justice" is directed to reduce the number of children who are arrested, detained, sentenced to imprisonment, and eliminate the stigma/label on children and return children to normal human beings so that they are expected to be useful both for families and for the future of the nation and nation. Regarding the meaning of restorative justice.

Yeni Widowaty argues that ${ }^{7}$ Restorative justice itself has the meaning of restoring justice. Restoration involves the restoration of relations between the victim and the perpetrator. Recovery of this relationship can be based on mutual agreement between the victim and the perpetrator. The victim can convey about the loss he suffered and the perpetrator was given the opportunity to redeem it, through compensation mechanisms, peace, social work, and other agreements. This is important because the conventional criminal process does not provide space for the parties involved, in this case the victims and perpetrators to actively participate in solving their problems.

\footnotetext{
${ }^{5}$ Bagir Manan dalam R. Wiyono, Hukum Acara Peradilan Tata Usaha Negara, Sinar Grafika, Jakarta,2013, p. 133-134.

${ }^{6}$ Nevey Varida Ariani, Implementasi Undang-Undang Nomor 11 Tahun 2012 Tentang Sistem Peradilan Pidana Anak dalam Upaya Melindungi Kepentingan Anak, Jurnal Media Hukum, I (Juni, 2014), p.9-10.

${ }^{7}$ Yeni Widowaty dan Fadia Fitriyanti, Membangun Model Perlindungan Hukum terhadap Masyarakat sebagai Korban Pencemaran dan/ atau Perusakan Lingkungan oleh Korporasi dengan Prinsip Restorative Justice, Jurnal Media Hukum, I (Juni,
} 2014), p. 13. 
The emergence of restorative justice is the beginning of the beginning of the settlement of criminal cases in achieving genuine justice, by bringing together the victims and perpetrators to produce an agreement that is equally fair for both parties, without any parties who feel disadvantaged or as victims of legal injustice in the rule of law.

Engage in restorative justice, in the Criminal Justice System Act the Child is not free from diversion arrangements. Without diversion, restorative justice in the handling of children as perpetrators of criminal acts will not be achieved. The importance of diversion in the context of realizing restorative justice as referred to in the Child Criminal Justice System Act, needs to be explained about diversion in the management of cases of children.

\section{2) Diversion}

According to Article 1 number 7 of the Child Criminal Justice System Law, diversion is the transfer of settlement of child cases from criminal justice processes to processes outside of criminal justice. The application of diversion provisions is an important thing to consider, because with the diversion of children's rights can be more secure, and prevent children from being stigmatized as "bad boy or criminal child", because a crime that is suspected of involving a child as an actor can be handled without having to through a judicial process. So that the form of child criminal liability that commits a crime is handled appropriately based on the concept of diversion as mandated in the Child Criminal Justice System Act.

The Child Criminal Justice System Law in the general explanation states that the most basic substance is strict regulation regarding restorative justice and diversion. This is intended to avoid and keep children away from the judicial process, so that they can prevent stigmatization of children facing the law and it is expected that children can return to the socila environment fairly.

Efforts to realize the goal of diversion cannot be separated from the components or subsystems of the juvenile justice system where every law enforcement apparatus, namely the Indonesian National Police, Attorney General's Office, and Courts in carrying out diversion duties must have the same objectives as intended in Article 6 of the Child Criminal Justice System Act . If one of the law enforcement apparatus in carrying out diversion duties has a goal that is not the same as other law enforcement officers, then the child criminal justice system will not succeed as desired by the Child Criminal Justice System Act.

It should be noted that not all child cases that commit criminal acts must be diversified. Based on Article 7 paragraph (1) the Child Criminal Justice System Law stipulates that at the level of investigation, prosecution and examination of cases of children in the District Court, diversion must be sought. In this case, what is meant by the phrase "child case" in Article 7 paragraph (1) of the Child Criminal Justice System Law is a case of a crime allegedly committed by a child. What is meant by "criminal cases" is a case about an act that is prohibited and threatened with crime, anyone who violates the prohibition.

The provisions contained in Article 7 paragraph (1) of the Child Criminal Justice System Law are associated with Article 7 paragraph (2) of the Child Criminal Justice System Law, so it can be seen that child cases must be attempted diversion when investigations, prosecutions and the examination in the District Court is the case of the child whose crime is:

1. Threatened with imprisonment under 7 (seven) years. Explanation of Article 7 paragraph (2) letter a of the Law on the Juvenile Justice System states that the provision "imprisonment under 7 (seven) years" refers to criminal law;

2. Not a repetition of a crime. Explanation of Article 7 paragraph (2) letter b of the Child Criminal Justice System Law states that repetition of criminal acts in this provision constitutes a criminal offense committed by a child, both similar and non-criminal, including criminal offenses through diversion.

b) Types of Sanctions for Children in the Child Criminal Justice System Act 
The Child Criminal Justice System Law is one of the Laws that has explicitly used two types of sanctions (double track system), namely in the form of criminal and action. Through the implementation of the double track system, it is expected to reflect justice both for the perpetrators, victims and the community. In order to make clear the types of sanctions for children in the form of crimes or actions, it is necessary to explain the types of criminal sanctions and actions for children based on the Law on the Juvenile Justice System.

1) Types of criminal sanctions for children Types of criminal sanctions for children based on the Law The juvenile justice system is distinguished by basic and additional criminal penalties. Based on Article 71 paragraph (1) of the Child Criminal Justice System Law, the principal penalty for Children consists of Criminal and Criminal penalties on condition. Criminal conditions, can be carried out in the following ways: Coaching outside the Institution, Community Services, Supervision, Job Training, Guidance in Institutions and Prisons.

2) Types of sanctions for children Based on the provisions of Article 82 of Act Number 11 of 2012, sanctions for actions that can be imposed on children include:

a. Returns to parents / guardians

b. Submission to someone

c. Care in a mental hospital

d. Care at the Social Welfare Organizing Agency (LPKS)

e. Obligation to take formal education and/or training conducted by the government or private entities.

f. Revocation of a driver's license.

g. Repairs due to criminal acts

3) Judges' consideration in imposing sanctions on children Judges as child case breakers in the form of sanctions for children, need to consider a number of considerations. The consideration of judges in determining the future of children in relation to the justice system in Indonesia places judges as the institution that most determines the fate of children without any interference from other parties. Judges' consideration in imposing sanctions for children is inseparable from the freedom of judges as referred to in Article 3 paragraph (1) and (2) of Law Number 48 of 2009 concerning the Principle of Organizing Judicial Power in essence stating that in dropping their duties and functions, constitutional judges must maintain judicial independence.

The purpose of independence of justice is that any interference in judicial affairs by other parties outside the judicial authority is prohibited, except in matters as referred to in the 1945 Constitution. The contents of the Article are reaffirmed in Article 5 paragraph (1) of Law Number 48 In 2009 concerning the Principle of Organizing Judicial Power which states that judges and constitutional judges must explore, follow and understand the legal values and sense of justice that live in society. The judge's consideration must be in accordance with the applicable rules in order to guarantee the protection and welfare of the child so that the type of sanction imposed is in accordance with the needs and best interests of the child.

According to Nanda Agung Dewantara that: The consideration of a judge or court is "gebonden vrijheid", which is bound/limited freedom because it is given a limit by laws that apply to a certain extent. The judge has the freedom to determine the type of crime (straafsoort), the size of the criminal or the severity of the criminal (strafmaat), how to implement the criminal (straf mode), and freedom to rechtvinding. ${ }^{8}$

The freedom and independence of judges must basically pay attention to various aspects so that the decisions taken can provide fair and beneficial decisions for justice seekers (justiciabelen) based on the truth and legal certainty. Although sometimes between justice and legal certainty, conflicts often occur, and if this happens, the judge in giving the decision must prioritize aspects of justice. Thus, for the sake of achieving a sense of justice for all parties, both for the perpetrators, victims and the community, a judicial basis is

${ }^{8}$ Nanda Agung Dewantara, 1987, Masalah Kebebasan Hakim dalam Menangani suatu Masalah Perkara Pidana, Jakarta, Aksara Persada, p. 51. 
needed in relation to this research, which is the basis for judges' consideration in imposing sanctions on children.

\section{1) Basic Considerations of Judges in Imposing Sanctions against Children}

The basis for judges' consideration in imposing sanctions on children as perpetrators of crimes, generally has the same basis as the judge's consideration in imposing sanctions on adults. This is based on Article 5 paragraph 2 letter b of the Law on the Juvenile Justice System which states that the trial of the Child is carried out by a court in the general court environment. The Supreme Court of the Republic of Indonesia as the highest body of the implementation of judicial power which supervises 4 (four) judicial bodies under it, namely general justice, religious justice, military justice, and state administrative courts, has determined that judges' decisions must consider all juridical, philosophical aspects , and sociology, so that justice that is to be achieved, realized, and accounted for in the judge's decision is justice oriented to legal justice (moral justice), moral justice, and social justice.

Based on the above description, more specifically that, the basis of the in-depth considerations conducted by the judge in the framework of imposing sanctions on children as perpetrators of crimes can be categorized as follows:

a. Juridical and Non-Juridical Considerations

Juridical considerations based on the opinion of Rusli Muhammad in relation to the discussion in this thesis, namely the consideration of judges in imposing sanctions for children as perpetrators of criminal acts, judicial judicial judgments consist of indictments of public prosecutors, Defendants' information, Witness statements, Evidence, Article-Article in the Criminal Law Regulations

Juridical factors related to criminal liability in children. The judge will consider whether the deed that has been done by the child can be accounted for to the child or not. Child criminal liability in criminal law is closely related to the age of the child. Based on the Juvenile Justice System Law, the age of a child who can be processed in a juvenile trial is a child who is 12 years old but not yet 18 years old. If the age of the responsibility of the child has been fulfilled, the judge will consider whether there is an element of an offense against the Child for the act being indicted. Bearing in mind that the condition of a Child's mistake for the act being charged is having to commit a criminal act (unlawful), above a certain age is able to be responsible, and has a form of error in the form of intentional or negligence and the absence of forgiving reasons. Fulfillment of the elements of errors in the child, having an impact on the child must be accountable for his actions. However, specifically for children as perpetrators of crimes, normalization must be sought for diversion.

Based on the facts revealed in the trial, the judge may seek diversion based on the provisions of diversion as discussed in section III A. If if the diversion attempt is reached, the judge will make a diversion determination letter. Conversely, if the diversion effort cannot be achieved or cannot be pursued, then the process of Juvenile Criminal Justice will be continued and end at the decision of the judge with all consideration of the judge.

Non-juridical considerations are subjective judges' judgments or their beliefs on the basis of Moral Justice and Social Justice, as well as the principles of justice, principles of benefit, and principles of legal certainty. Moral Justice means that the Judge underlies consideration in adjudicating and deciding cases of child crimes in addition to paying attention to positive law, must also consider non-juridical considerations that are philosophical, sociological, psychological, and criminological ${ }^{9}$.

The characteristics of non-judicial considerations are explained as follows: Philosophical, Sociological, Psychological, Criminological Based on the characteristics of the judicial nonjudicial considerations outlined above, according to Rusli Muhammad what is meant by nonjuridical considerations is "the background of committing a crime, the consequences, the

${ }^{9}$ Made Agus Indra Diandika dan I Ketut Sudantra, 2013, Dasar Pertimbangan Hakim dalam Menjatuhkan Pidana Penjara terhadap Anak, (Paper, Fakultas Hukum Universitas Udayana, Bali), p. 3. 
condition of the defendant, the socio-economic conditions and the environment of the defendant's family and religious factors".

The judicial non-judicial considerations as described by Rusli Muhammad in relation to the imposition of sanctions for children as perpetrators of crimes are described as follows Children's background, As a result of the child's actions, Child's condition, Child Religion.

In order to support the basis of the non-judicial considerations, based on Article 60 paragraph (3) of the Child Criminal Justice System Law, the Judge must consider the social research report of the Community Advisor before deciding the case decision. The research report referred to in Article 60 paragraph (3) of the Child Criminal Justice System Act is carried out by the Correctional Center, where based on Article 57 paragraph (2) of the Child Criminal Justice System Act, the social research report contains:

a. Personal data on Children, family, education and social life.

b. The background of committing a crime.

c. The situation of the victim in the event that there is a victim in a crime against the body or life.

d. Other things deemed necessary.

e. News of diversion.

f. Conclusions and recommendations from Community Counselors.

The social research report is intended to reveal and find data and information objectively, about the development and background of the child's life from various sociological, psychological and other aspects. Data and information about all matters relating to children are ultimately used as a basis for community guidance in delivering recommendations to judges about what sanctions are appropriate for children while still taking into account the best interests of the child. It is also confirmed based on Article 60 paragraph (4) of the SPPA Law stating that if the social research report is not considered in the Judge's decision, then the decision is null and void.

The next aspect is Social Justice, where the Judge does not live on the throne but lives socializing with the heterogeneous community environment. Thus the Judge in upholding positive law (law in book) can realize social justice (law in action), so that the Judge's decision in the case of child crimes has the dimension of giving justice that is beneficial for the child's interest as well as the social environment including the parents and surrounding community. It is the facts in the trial and the principles that form the basis of whether the sanctions are fair enough to be carried out by the actions taken ${ }^{10}$.

b. Incriminating and Relieving Things

Judges' consideration in imposing sanctions on children other than the judicial basis of judicial and non-juridical considerations, according to Sri Rahayu Sundari, is a factor that influences sanctions, namely ${ }^{11}$ :

Things that burden the punishment are divided into three, namely Position as Officer (Article 52 of the Criminal Code), Repetition of Criminal Actions (Residive), Combined /Samenloop

c. Crime by using the National Flag of the Republic of Indonesia

The connection with the case of the child as a criminal offender based on incriminating matters as described above, is not possible if the child commits a criminal offense in office considering the child's age is still at the age of the student. Things that alleviate punishment are divided into three, namely Experiment (Poging), Assistance (Medeplictige), Not old enough (Minderjarig). Is $^{12}$ :

According to J. E. Sahetapy, things alleviated during the trial

\footnotetext{
${ }^{10}$ Made Agus Indra Diandika dan I Ketut Sudantra, Op. Cit, p. 4.

${ }^{11}$ Sri Rahayu Sundari dalam Nashriana, Hukum Penitensier, UNSRI, Palembang, 2005, p.18-20. 25.

12 J. E. Sahetapy, 2009, Ancaman Pidana Mati terhadap Pembunuhan Berencana, Malang, Setara Press, hlm. 302.
} 
1) The defendant's correct and respectful attitude towards the court, and candid recognition so as to facilitate the proceedings.

2) There are no motives related to the public's background in this crime.

3) In the trial, the defendant expressed remorse for his actions.

4) The defendant was not proven to have participated in a trial attempt by several individuals who would violently escape from prison.

5) The defendant has never been convicted of a criminal case.

The mention of "defendant" based on the opinion of J. E. Sahetapy in relation to this research is that the Child is a criminal offender, hereinafter referred to as the Child.

Based on the things that are burdensome and things that alleviate the effect of imposing sanctions by judges, there can be potential for a criminal disparity. Thus in the consideration of judges in the imposition of sanctions can not be separated from the criminal disparity.

\section{Conclusion}

The concept of decision making in the diversion process for children facing the law that is not yet 12 years old is the judge in imposing sanctions for children considering recommendations in the social research report made by community counselors to express and find data and information objectively about the development and background of life children from various sociological, psychological and other aspects while still paying attention to the best interests of the child.

\section{Reference}

[2] Bagir Manan dalam R. Wiyono, Hukum Acara Peradilan Tata Usaha Negara, Sinar Grafika,Jakarta,2013.

[3] Nevey Varida Ariani, Implementasi Undang-Undang Nomor 11 Tahun 2012 Tentang Sistem Peradilan Pidana Anak dalam Upaya Melindungi Kepentingan Anak, Jurnal Media Hukum, I (Juni, 2014).

[4] Yeni Widowaty dan Fadia Fitriyanti, Membangun Model Perlindungan Hukum terhadap Masyarakat sebagai Korban Pencemaran dan/ atau Perusakan Lingkungan oleh Korporasi dengan Prinsip Restorative Justice, Jurnal Media Hukum, I (Juni, 2014).

[5] Nanda Agung Dewantara, 1987, Masalah Kebebasan Hakim dalam Menangani suatu Masalah Perkara Pidana, Jakarta, Aksara Persada.

[6] Made Agus Indra Diandika dan I Ketut Sudantra, 2013, Dasar Pertimbangan Hakim dalam Menjatuhkan Pidana Penjara terhadap Anak, (Paper, Fakultas Hukum Universitas Udayana, Bali).

[7] Sri Rahayu Sundari dalam Nashriana, Hukum Penitensier, UNSRI, Palembang, 2005.

[8] J. E. Sahetapy, 2009, Ancaman Pidana Mati terhadap Pembunuhan Berencana, Malang, Setara Press.

[9] The Criminal Procedure Code (KUHAP).

[10] Law Number 35 of 2014 concerning Amendments to law number 23 of 2002 concerning Child Protection

[11] Republic of Indonesia Government Regulation Number 65 of 2015 concerning Guidelines for Implementing Diversion and Handling of Children Not Aged 12 (Twelve) Years Old 